\title{
Antibacterial Efficacy of Zinc Oxide and Titanium Dioxide Nanoparticles against Escherichia coli in Minced Meat
}

\author{
Mohebat A. Abd El-Aziz ${ }^{1 *}$, Hemmat M. Ibrahim ${ }^{2}$, Nahla Abo EL-Roos ${ }^{1}$, Badawi Anis $^{3}$, and Rasha Elsabagh ${ }^{2}$ \\ ${ }^{I}$ Food Hygiene Animal Health Research Institute, Egypt \\ ${ }^{2}$ Food Hygiene and Control Department, Faculty of Veterinary Medicine, Benha University, Egypt \\ ${ }^{3}$ Spectroscopy Department, Physics Division, National Research Centre, 33 El Bohouth St. (former El Tahrir St.), Dokki, P.O. 12622, Giza, Egypt \\ *Corresponding author's Email: pepovet79@yahoo.com; (DORCiD: 0000-0002-3820-2885
}

\begin{abstract}
Antibacterial nanoparticles are a new approach to control the safety of meat and meat products. This work aimed to investigate the antibacterial effect of zinc oxide $(\mathrm{ZnO})$ and titanium dioxide $\left(\mathrm{TiO}_{2}\right)$ nanoparticles, alone or together, against Escherichia coli. Antibacterial activity of these nanomaterials was evaluated using the disc diffusion method. In this regard, minced meat samples were inoculated with $E$. coli and treated with different concentrations of two nanomaterials (approximately $20 \mathrm{~nm}$ ), including $6 \mathrm{mM}$ and $12 \mathrm{mM} \mathrm{ZnO,} 6 \mathrm{mM}$ and $12 \mathrm{mM} \mathrm{TiO} 2$, and a combination of $6 \mathrm{mM} \mathrm{ZnO}$ and $6 \mathrm{mM} \mathrm{TiO} 2$, then stored at $4^{\circ} \mathrm{C}$ for 17 days. The results indicated that $\mathrm{ZnO}(12 \mathrm{mM})$ had a significant reduction effect on $E$. coli count in minced meat, followed by the combination of $\mathrm{ZnO}$ and $\mathrm{TiO} 2$, and $12 \mathrm{mM} \mathrm{TiO} 2$ alone. The antibacterial activity of $\mathrm{ZnO}, \mathrm{TiO} 2$, and combination of $\mathrm{ZnO}$ and $\mathrm{TiO} 2$ was also examined using a transmission electron microscope and it was found that $12 \mathrm{Mm} \mathrm{ZnO}$ had a higher destructive effect on bacterial cell than the mixture of $\mathrm{ZnO}+\mathrm{TiO} 2$, and $12 \mathrm{Mm} \mathrm{TiO} 2$ alone. The disc diffusion method showed that $\mathrm{ZnO}(12 \mathrm{mM})$ was the most effective concentration used against E. coli. It is concluded that $12 \mathrm{mM} \mathrm{ZnO}$ nanoparticles have the best antibacterial effect against $E$. coli in minced meat stored at $4{ }^{\circ} \mathrm{C}$ for 17 days.
\end{abstract}

Keywords: E. coli, Minced meat, Nanoparticles, TEM, Titanium dioxide, Zinc oxide

\section{INTRODUCTION}

Increasing meat consumption throughout the world presents excessive challenges to meat safety and hygiene (Sofos and Geornaras, 2010). Meat product deterioration during distribution and exposure through the markets has negative effects on the meat industry from an economic point of view (Domínguez et al., 2018). Ground meat not only is highly susceptible to spoilage, but also is frequently involved in the spread of pathogens (Ahmed and Ismail, 2010) especially pathogenic strains of $E$. coli (Marcous et al., 2017), therefore, it is necessary to search for substances that are effective against bacteria especially $E$. coli and improve the microbiological condition of ground meat. Source tracking of $E$. coli is the main step to control foodborne infections (Liu et al., 2019). Great efforts are being made in the food industry for improving hygiene and increasing the shelf life of meat products through preventing the growth and multiplication of food-borne pathogens (Baltić et al., 2013).

Nanotechnology can provide the method that can be applied throughout different aspects of the food chain processing to improve food safety and quality control and increase food shelf life (Baltić et al., 2013). The most important nanomaterials that commonly used for antibacterial activity in the food industry are oxides of zinc ( $\mathrm{Zn}$ ) and titanium (Ti) (Duncan, 2011). Titanium dioxide $\left(\mathrm{TiO}_{2}\right)$ and zinc oxide $(\mathrm{ZnO})$ nanoparticles are known to be one type of inorganic multifunctional substances that are able to inhibit the growth of microbes and they have been listed as Generally Recognized As Safe (GRAS) by the U.S. FDA (Zambrano-Zaragoza et al., 2018). These nanoparticles act as biocides and do not have any toxic effect and have approved by FDA for application in food processing fields (Toker et al., 2013). TiO2 is commonly used as a food additive and authorized for use in the European Union as E171 (Directive, 1994).

It is supposed that the toxicity of nanoparticles depends on their morphology, size, and amount consumed. Although possible risk to human health after eating food having TiO2 nanoparticles has been poorly explored, scientific databases inform that $\mathrm{TiO} 2$ nanoparticles can induce inflammation due to oxidative stress and also can have a genotoxic effect leading to chromosomal instability (Baranowska et al., 2020).

The antibacterial effect of $\mathrm{TiO}_{2}$ and $\mathrm{ZnO}$ nanoparticles against E. coli $\mathrm{O} 157: \mathrm{H} 7$ in fresh calf minced meat have been investigated (Marcous et al., 2017). The antibacterial activity of $\mathrm{TiO}_{2}$ nanoparticle against E. coli was investigated by Othman et al. (2014), who proved the importance of $\mathrm{TiO} 2$ nanoparticles for ensuring the safety of food. 
One of the most important ways for applications of nanomaterials in food and meat is to place nanoparticles directly into food as food additives (Coles and Frewer, 2013) to preserve colors and prevent spoilage (Xie et al., 2011). Most previous studies link nanoparticles to external coating or packaging of meat but these methods are not appropriate for use in the minced meat industry. In addition, EFSA (2008) and Avella et al. (2005) supposed that migration of nanoparticle from packaging materials is either nil or very low, therefore, this study aimed to examine the antibacterial effect of $\mathrm{ZnO}$ and $\mathrm{TiO} 2$ nanoparticles, alone or together, directly mixed with minced meat. Also, the present study evaluated the in vitro antimicrobial effect of these nanomaterials against $E$. coli.

\section{MATERIALS AND METHODS}

The experiment was conducted in the Animal Health Research Institute, Egypt.

\section{Minced beef}

Fresh minced beef used in this study was purchased and immediately transported to the laboratory in an icebox and stored at $4{ }^{\circ} \mathrm{C}$ until use. Thin sheets of minced beef were treated with ultraviolet light (wavelength $385 \mathrm{~nm}$ ) for $30 \mathrm{~min}$, $15 \mathrm{~min}$ to each side to eliminate background microflora (Morsy et al., 2018).

\section{Bacterial strain}

Escherichia coli $\left(\mathrm{ATCC}^{\circledR} 25922^{\mathrm{TM}}\right) \sim 8 \log \mathrm{CFU} / \mathrm{ml}$ was used in this study and obtained from Media Unit, Food Hygiene Department, Animal Health Research Institute, Dokki, Giza, Egypt.

\section{Synthesis and preparation of zinc oxide nanoparticles}

Zinc oxide nanoparticles were prepared by dissolving $11 \mathrm{~g}$ zinc acetate hydrate with $99.9 \%$ purity $\left(\mathrm{Zn}(\mathrm{Ac})_{2} \bullet 2 \mathrm{H} 2 \mathrm{O}\right.$, Sigma-Aldrich) in $500 \mathrm{ml}$ ethanol. Then, $2.9 \mathrm{~g}$ sodium hydroxide was added into the solution through ultra-sonication, and a transparent solution was obtained. The conical flask containing the transparent solution was put into a water tank with a constant temperature of $60^{\circ} \mathrm{C}$. After that, $10 \mathrm{ml}$ of distilled water was added to the solution into the conical flask. The solution was stirred for $30 \mathrm{~min}$ at $60{ }^{\circ} \mathrm{C}$. The prepared $\mathrm{ZnO}$ nanoparticles were collected by centrifuging and drying at $60{ }^{\circ} \mathrm{C}$ (Wang et al., 2007).

\section{Synthesis and preparation of titanium dioxide nanoparticles}

Titanium tetrachloride $\left(\mathrm{TiCl}_{4}\right)($ Fluka $98 \%)$ was used as a starting material. $\mathrm{TiO} 2$ nanoparticles were prepared by dropwise addition of $4 \mathrm{ml}$ of $\mathrm{TiCl}_{4}$ into $400 \mathrm{ml}$ of water/ethanol solution $(3: 1)$ at $0{ }^{\circ} \mathrm{C}$ with vigorous stirring. Subsequently, a dilute solution of $\mathrm{NH}_{4} \mathrm{OH}$ was used to adjust the $\mathrm{pH}$ at 9 . The solution was refluxed for $4 \mathrm{~h}$ with continues stirring. Then the solution was cooled down to room temperature naturally. The TiO2 nanoparticles were obtained by centrifuging at $4000 \mathrm{rpm}$. The formed $\mathrm{TiO} 2$ was washed using acetone several times and then dried at 100 ${ }^{\circ} \mathrm{C}$ for $5 \mathrm{~h}$. The powder was annealed at $400{ }^{\circ} \mathrm{C}$ in air for $2 \mathrm{~h}$ by raising the temperature at a rate of $10{ }^{\circ} \mathrm{C} / \mathrm{min}(\mathrm{Yin}$ et al., 2001).

\section{Assessment of in vitro antibacterial activity of nanomaterials using disc diffusion method}

To assess the inhibitory range of nanoparticles of $\mathrm{ZnO}(2,3,5,6$, and $12 \mathrm{mM})$ and $\mathrm{TiO} 2(3,4,5,6$, and 12mM) against $E$. coli, they were suspended in double-distilled water and constantly stirred until a uniform colloidal suspension was formed to yield solutions of different concentrations. An appropriate volume of test bacteria was inoculated on Mueller-Hinton agar medium. Sterile paper discs (Whatman No.1, $6 \mathrm{~mm}$ in diameter) were placed on the surface of suitable media plates freshly inoculated with bacterial cells, then $10 \mu \mathrm{L}$ from each dilution was dispensed onto the surface of each disc. Plates were then incubated for $24 \mathrm{~h}$ at $37^{\circ} \mathrm{C}$ (Bauer et al., 1966).

\section{Assessment of antibacterial activity of nanomaterials in minced meat}

In a sterile bag, minced meat was inoculated with $E$. coli $(\sim 8 \log \mathrm{CFU} / \mathrm{ml})$ to achieve final concentration $\sim 6 \log$ $\mathrm{CFU} / \mathrm{g}$ of minced meat. Then, they were mixed thoroughly by gently squeezing the bags by hand till even distribution of microbe occurred, and left for $30 \mathrm{~min}$ for complete attachment between inoculated $E$. coli and minced meat. The initial load of E. coli was determined before the addition of nanomaterials. Phosphate buffer saline (PBS) was used for the treatment of control samples. Minced meat sample was divided into six groups (200 g each); Group 1 (PBS + E. coli), Group $2(6 \mathrm{mM} \mathrm{ZnO}+$ E. coli $)$, Group $3(6 \mathrm{mM} \mathrm{TiO} 2+$ E. coli $)$, Group $4(12 \mathrm{mM} \mathrm{ZnO}+$ E. coli $)$, Group $5(12 \mathrm{mM} \mathrm{TiO} 2+$ E. coli $)$, and Group $6(6 \mathrm{mM} \mathrm{ZnO}+6 \mathrm{mM} \mathrm{TiO} 2+E$. coli $)$. Nanomaterials were mixed with the minced beef samples for a further 30 seconds to ensure even mixing. All samples were transferred individually into a standard sterile polyethylene bag (self-closed). Packed samples were labeled and kept at $4 \pm 1{ }^{\circ} \mathrm{C}$ till spoilage of minced meat. Counting of E. coli and sensory evaluation were performed on days $0,3,6,9,12,15$, and 17 . The experiment was repeated in triplicate for each group and mean values were calculated. 


\section{E. coli enumeration}

Accurately, $100 \mu \mathrm{l}$ from each previously prepared serial dilution was spread over duplicated plates of EMB agar (OXOID, CM0 069) using a sterile bent glass spreader. The inoculated and control plates were incubated at $37{ }^{\circ} \mathrm{C}$ for 24 h (FDA, 2001). The suspected colonies of E. coli were greenish metallic colonies with a dark purple center. These colonies were enumerated and expressed as $\log \mathrm{CFU} / \mathrm{g}$ of sample.

\section{Electron microscopy observations}

Transmission Electron Microscopy (TEM) techniques used to evaluate biocidal action of nanomaterials on E. coli using TEM Negative Staining method. JEOL JEM1400 transmission electron microscope was used (Yashroy, 1990). TEM was conducted in Cairo University Research Park, Egypt.

\section{Sensory evaluation}

Sensory evaluation was performed under the controlled condition of temperature $\left(28{ }^{\circ} \mathrm{c}\right)$, humidity $(65 \%)$, and light by five well-trained female panelists of 30 to 35 years of age, who were selected according to ISO (2012). The panelists were able to perform descriptive sensory analysis for treated samples and control one and give reliable comparative judgments. The criteria used as the basis of the organoleptic descriptive assessment and the samples were rated on a continuous hedonic scale (ISO, 2003). The panel received a list of descriptors (odor, color, and texture) to score on numerical and continuous scales from 0 (the lowest score for each attribute, very bad) to 10 (the highest score for each attribute, very good) according to Cullere et al. (2018). Every one of panelists took disposable dish containing three samples (two identical and another different) in triangle form randomly coded with four numbers and worksheet to give the score for each point. A mean score of lower than 5 indicated unacceptable quality. Totally, 210 samples (50 g) were examined on 7 sessions, 30 samples per session on five rounds per session at $1^{\text {st }}$ day, $3^{\text {rd }}$ day, $6^{\text {th }}$ day, $9^{\text {th }}$ day, $12^{\text {th }}$ day, $15^{\text {th }}$ day and $17^{\text {th }}$ day.

\section{Statistical analysis}

The experiment was designed in completely randomized design in a $6 \times 7$ factorial design; 6 treatments $(6 \mathrm{mM} \mathrm{ZnO}$, $12 \mathrm{mM} \mathrm{ZnO}, 6 \mathrm{mM}$ TiO2, $12 \mathrm{mM}$ TiO $2,6 \mathrm{mM}$ of $\mathrm{ZnO}+\mathrm{TiO} 2$ and control one $)$ during 7 sampling days $\left(1^{\text {st }}\right.$ day, $3^{\text {rd }}, 6^{\text {th }}$, $9^{\text {th }}, 12^{\text {th }}, 15^{\text {th }}$ and $\left.17^{\text {th }}\right)$ at refrigerated storage $\left(4 \pm 1^{\circ} \mathrm{C}\right)$. The experimental model was made according to Butler et al. (2009). All data were subjected to analysis of variance (ANOVA) using SPSS program for Windows (Version 22) (SPSS Inc. Chicago, IL, USA). F-values at the $\mathrm{p} \leq 0.05$ were indicated significantly different. Duncan's multiple range test was used for measuring the specific differences between pairs of means (Duncan, 1955). Values presented as the means \pm standard error

\section{RESULTS AND DISCUSSION}

\section{In vitro antibacterial activity of nanomaterials using disc diffusion method}

As shown in table 1, zones of inhibition were differed according to the concentration of nanoparticles used. Results showed that $12 \mathrm{mM} \mathrm{ZnO}$ had the widest inhibition zone, followed by $12 \mathrm{mM} \mathrm{TiO} 2,6 \mathrm{mM} \mathrm{ZnO}$, and $6 \mathrm{mM} \mathrm{TiO} 2$. While $2 \mathrm{mM} \mathrm{ZnO}$ and $3 \mathrm{mM} \mathrm{TiO} 2$ do not show any antibacterial effect. According to a study, $3 \mathrm{mM}$ and $6 \mathrm{mM}$ concentrations of $\mathrm{ZnO}$ nanoparticles resulted in less bacterial growth compared to the control, while the growth of E. coli O157:H7 was completely inhibited by $12 \mathrm{mM} \mathrm{ZnO}$ nanoparticles (Liu et al., 2009). The antibacterial action of ZnO nanoparticle was studied by Emami-Karvani and Chehrazi (2011) against Gram-negative bacteria (E. coli) were used as test microorganisms. It was found that the antibacterial activity of $\mathrm{Zn} \mathrm{O}$ nanoparticles increased with decreasing particle size 20 nanometers and increasing powder concentration $12 \mathrm{mM}$. These small concentrations were able to prevent the growth of E. coli on its media so we used it in our challenge study.

Table 1. Antibacterial activity assessment of nanoparticles against $E$. coli using disc diffusion method

\begin{tabular}{lc}
\hline Nanoparticle (concentration) & Zone of inhibition(mm) \\
\hline $\mathrm{ZnO}(2 \mathrm{mM})$ & $\mathrm{ND}^{*}$ \\
$\mathrm{ZnO}(3 \mathrm{mM})$ & $6 \pm 0.12$ \\
$\mathrm{ZnO}(5 \mathrm{mM})$ & $7.5 \pm 0.11$ \\
$\mathrm{ZnO}(6 \mathrm{mM})$ & $10 \pm 0.10$ \\
$\mathrm{ZnO}(12 \mathrm{mM})$ & $15 \pm 0.14$ \\
$\mathrm{TiO}_{2}(3 \mathrm{mM})$ & $\mathrm{ND}$ \\
$\mathrm{TiO}_{2}(4 \mathrm{mM})$ & $6 \pm 0.02$ \\
$\mathrm{TiO}_{2}(5 \mathrm{mM})$ & $7 \pm 0.025$ \\
$\mathrm{TiO}_{2}(6 \mathrm{mM})$ & $8 \pm 0.22$ \\
$\mathrm{TiO}_{2}(12 \mathrm{mM})$ & $13 \pm 0.11$ \\
\hline $\mathrm{ND}^{*} \mathrm{~N}$
\end{tabular}




\section{Electron microscopy observations on nanoparticle against $E$. coli}

Figure 1 shows normal E. coli with an intact cell membrane (control one). As shown in figure 2 , $\mathrm{ZnO}$ had the largest effect on bacterial cell as it affects the cell wall of bacteria so it becomes irregular, perforated, swelling, and over enlargement. Figure 3 shows the accumulation of nanoparticles ( $\mathrm{ZnO}$ and $\mathrm{TiO} 2)$ around the bacterial surface and agglomeration of cytoplasmic material. These results were in agreement with the findings of Ashe (2011), who reported $\mathrm{ZnO}$ nanoparticles are bactericidal and disrupt membrane thus cause membrane dysfunction, resulting in leakage the content outside and cell death. There are components found in Gram-negative bacteria, and not in Gram-positives, which can oppose nanoparticles to attachment onto cell walls; the possible mechanism is the extra layer of outer membranes and the pathogen-associated molecular patterns which include lipopolysaccharide and particular fragments of peptidoglycan. Bacterial cell wall properties can play a crucial role in the diffusion of nanoparticles inside the bacterial cell (Espitia et al., 2012). Figure 4 shows the effect of TiO2 on E.coli was less affected by TiO2 compared to ZnO, which showed over swelling and thinning of cell wall. The antibacterial effect of $\mathrm{TiO}_{2}$ on some bacteria such as $E$. coli has been studied (Mihaly et al., 2015).

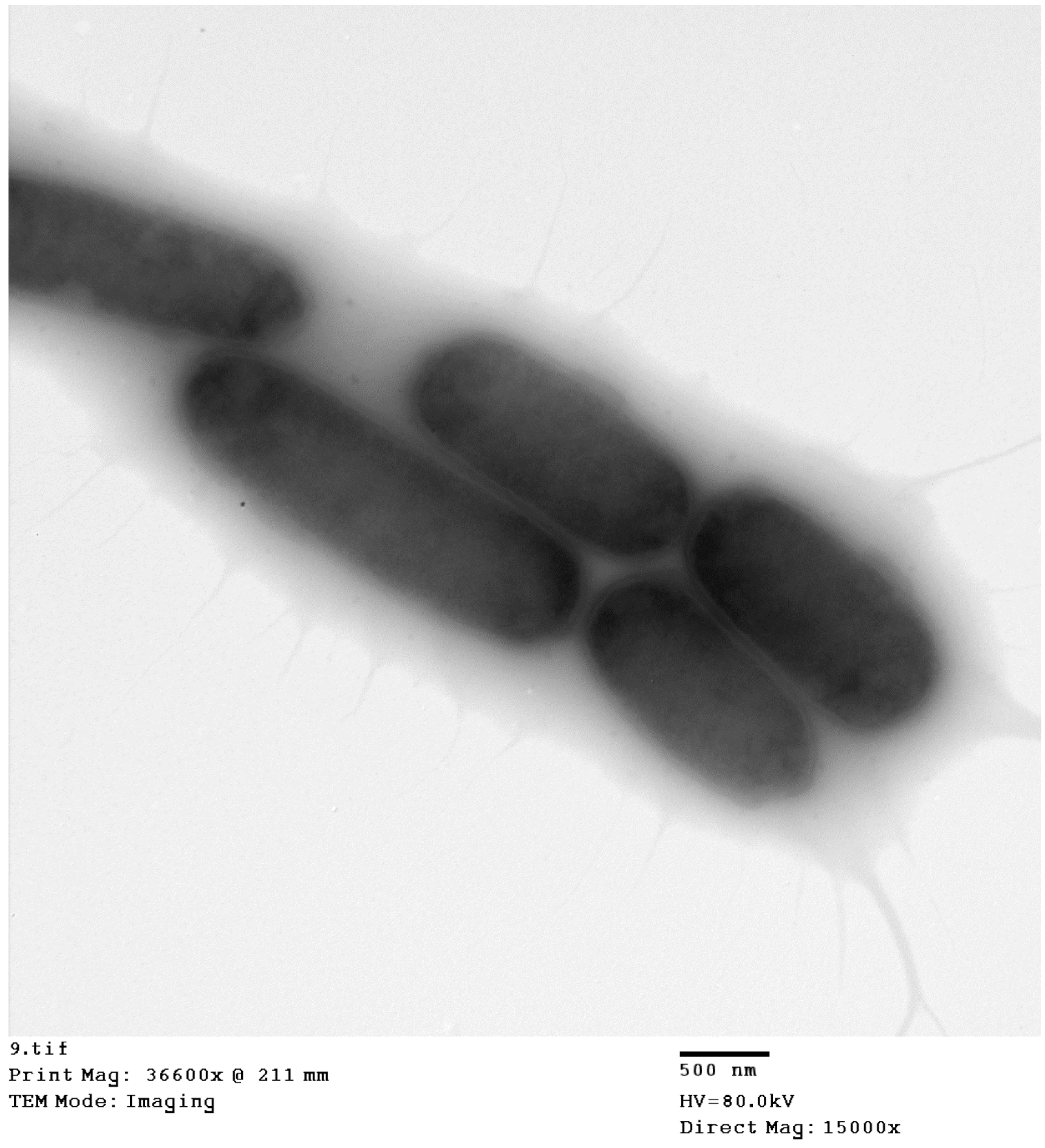

Figure 1. Normal morphology of E. coli using transmission electron microscope 


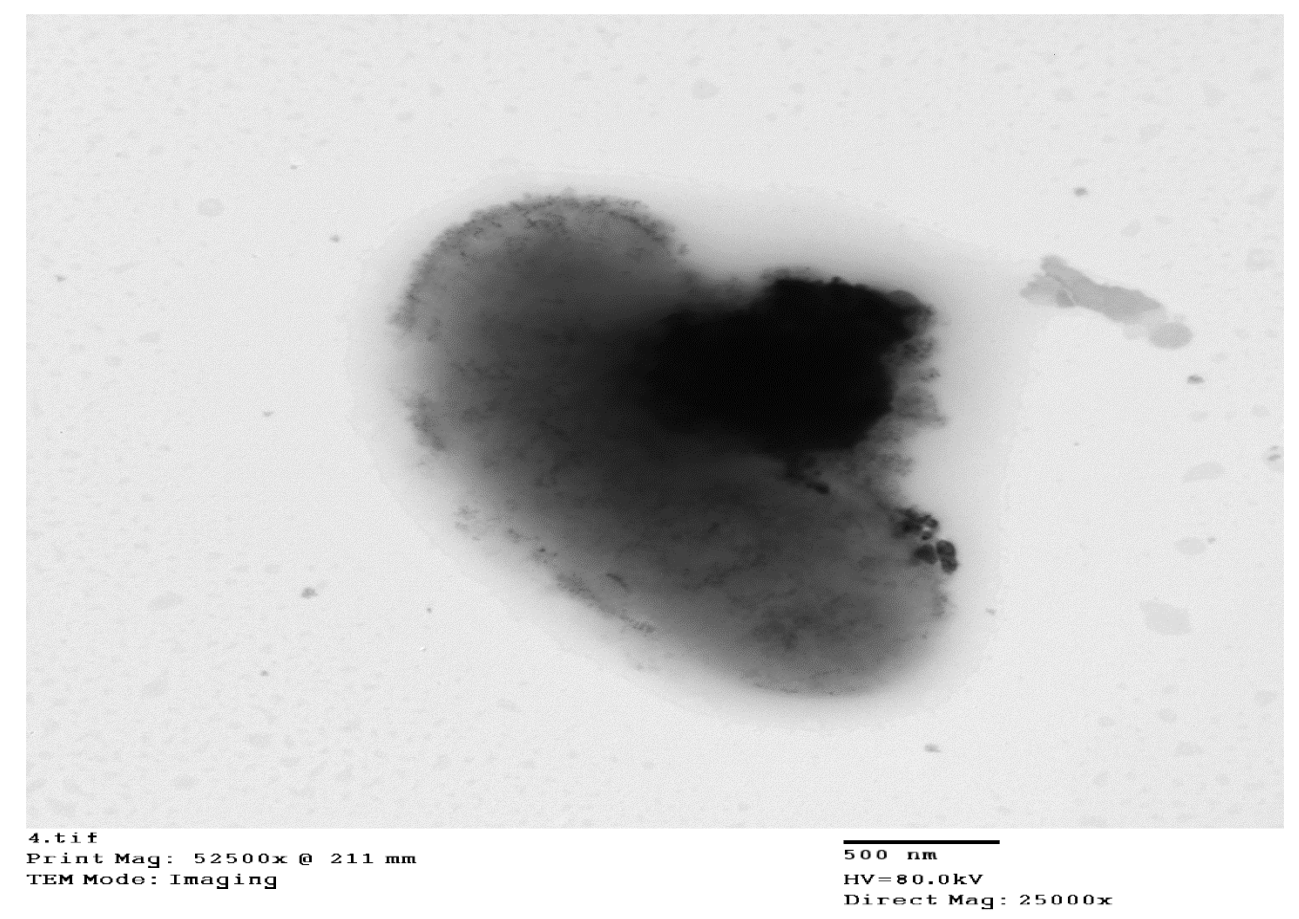

Figure 2. Antibacterial activity of $\mathrm{ZnO}$ nanoparticles against $E$. coli evaluated by transmission electron microscopy. $\mathrm{ZnO}$ nanoparticles adhered to $E$. coli cause pores in cell wall, elongation of cell, and ruptured cell.

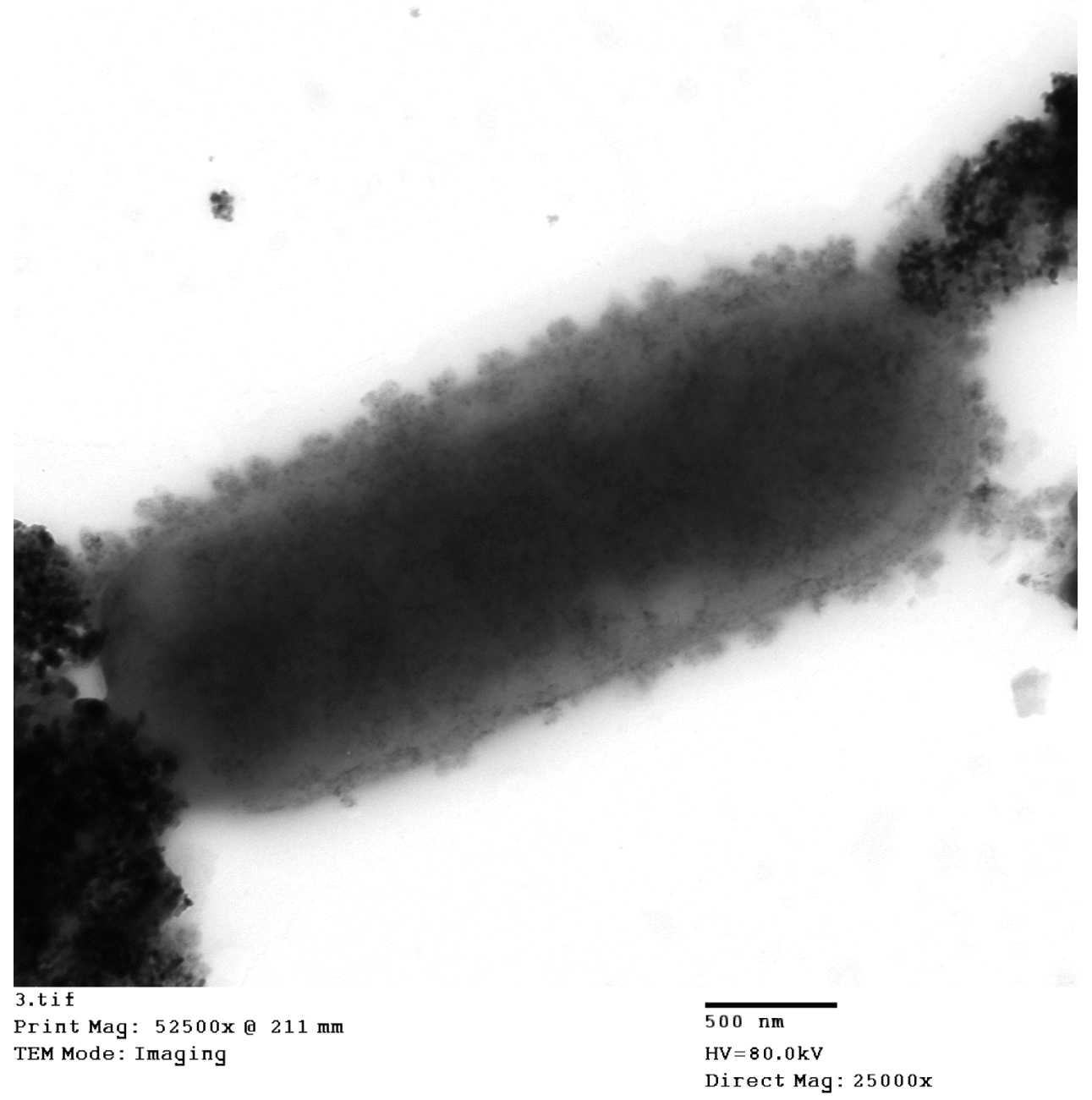

Figure 3. Antibacterial activity of nanoparticles mixture $(\mathrm{ZnO}+\mathrm{TiO} 2)$ against E. coli evaluated by transmission electron microscopy. Nanoparticles accumulated around the bacterial cell cause elongation of cell and disruption of cytoplasm. 


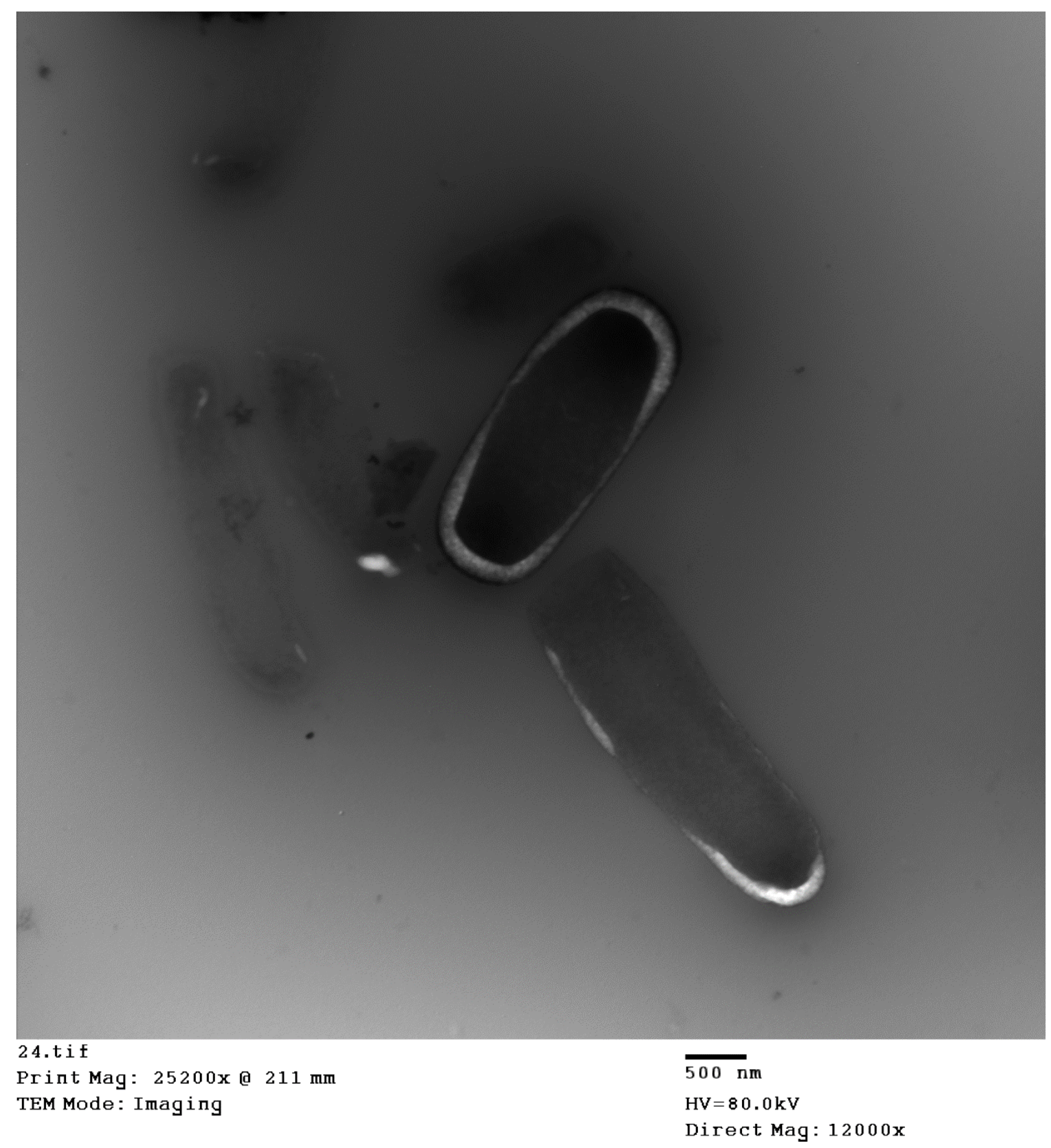

Figure 4. Antibacterial activity of $\mathrm{TiO} 2$ nanoparticles against $E$. coli evaluated by transmission electron microscopy. $\mathrm{TiO} 2$ caused elongation of cell, thinning of cell wall and pores in plasma membrane

\section{E. coli count in minced meat stored at $4{ }^{\circ} \mathrm{C}$}

The effect of nanoparticles on the count of inoculated $E$. coli in minced meat during storage at $4{ }^{\circ} \mathrm{C}$ is presented in table 2. E. coli counts increased in the control sample during the storage period of minced meat by $\sim 2-4 \log (\mathrm{CFU} / \mathrm{g})$, which was significantly different from all treated samples. Count of E. coli in nanoparticles treated samples decreased throughout storage, indicating antibacterial activity of nanoparticles. $\mathrm{ZnO}(12 \mathrm{mM})$ exhibited great antibacterial effect against $E$. coli and it decreased the count by $\sim 5 \log (\mathrm{CFU} / \mathrm{g})$ which was significantly different from the effects of obtained by the mixture of $\mathrm{ZnO}+\mathrm{TiO} 2(6 \mathrm{mM})$ and $\mathrm{TiO} 2(12 \mathrm{mM})$ which decreased the count by $\sim 4 \mathrm{log}$ (CFU/g). Also, $\mathrm{ZnO}(6 \mathrm{mM})$ and $\mathrm{TiO} 2(6 \mathrm{mM})$ decreased the count by $\sim 2 \log (\mathrm{CFU} / \mathrm{g})$. These results are nearly similar to the findings of Marcous et al. (2017) who examined the antibacterial action of $\mathrm{ZnO}$ and $\mathrm{TiO} 2$, alone and together, against $E$. coli in calf minced meat and reported that $\mathrm{ZnO}$ was the most effective antimicrobial nanoparticles. $\mathrm{ZnO}$ nanoparticles are a novel material controlling foodborne pathogens, thus can be applied for food safety (Ali et al., 2020). Also, Morsy et al. (2018) studied the synergistic antimicrobial effect of $\mathrm{ZnO}$ nanoparticle and other compounds as nisin, lysozyme and EDTA nanoparticles on different foodborne pathogens including E. coli O157:H7 and proved that $\mathrm{ZnO}$ has great antimicrobial 
effect. As $\mathrm{ZnO}$ nanoparticles have great antibacterial activity, it has received significant interest worldwide particularly by the implementation of nanotechnology. Reduction of the particle size of $\mathrm{ZnO}$ nanoparticles leads to an increase in the particle surface reaction thus it exhibits great antibacterial activity (Sirelkhatim et al., 2015). Many studies investigated the effect of $\mathrm{ZnO}$ and $\mathrm{TiO} 2$ nanoparticles on E. coli at concentrations near concentrations used in this study but a very small diameter used in this study enhanced the effect of these nanoparticles. The concentrations of nanoparticles used in this study were less than the permissible limits approved by FDA (2015). ZnO and TiO2 nanoparticles are cheap antibacterial substances that have a wide range of antibacterial activity against microbes present in meat, therefore, they help to ensure the quality of meat, increase the shelf life for minced meat, and maintain the health of human.

Table 2. Antibacterial activity of different concentrations of $\mathrm{ZnO}$ and $\mathrm{TiO} 2$ nanoparticles against $E$. coli counts on minced beef inoculated with $E$. coli $\left(\sim 6 \log \mathrm{CFU} / \mathrm{g}\right.$ of minced meat) during storage at $4{ }^{\circ} \mathrm{C}$ for 17 days

\begin{tabular}{|c|c|c|c|c|c|c|c|}
\hline Groups & 1st day & 3rd day & 6th day & 9th day & 12th day & 15th day & $17^{\text {th }}$ day \\
\hline Control group & $6.41 \pm 0.26^{\mathrm{a}}$ & $6.28 \pm 0.22^{a}$ & $7.14 \pm 0.1^{\mathrm{a}}$ & $8.64 \pm 0.32^{\mathrm{a}}$ & $8.95 \pm 0.6^{\mathrm{a}}$ & $8.99 \pm 0.73^{a}$ & $9.22 \pm 0.14^{\mathrm{a}}$ \\
\hline $12 \mathrm{mM} \mathrm{ZnO}$ & $6.03 \pm 0.6^{\mathrm{a}}$ & $5.38 \pm 0.2^{c}$ & $5.35 \pm 0.1^{\mathrm{d}}$ & $4.78 \pm 0.21^{\mathrm{c}, \mathrm{d}}$ & $3.60 \pm 0.2^{\mathrm{d}}$ & $1.65 \pm 0.14^{\mathrm{c}}$ & $1.31 \pm 0.9^{\mathrm{e}}$ \\
\hline $6 \mathrm{mM} \mathrm{ZnO}+6 \mathrm{mM} \mathrm{TiO} 2$ & $6.16 \pm 0.7^{\mathrm{a}}$ & $5.55 \pm 0.3^{c}$ & $5.21 \pm 0.1^{\mathrm{d}}$ & $4.33 \pm 0.19^{d}$ & $4.47 \pm 0.3^{c}$ & $2.11 \pm 0.3^{c}$ & $2.02 \pm 0.10^{\mathrm{d}}$ \\
\hline $12 \mathrm{mM} \mathrm{TiO} 2$ & $6.38 \pm 0.8^{\mathrm{a}}$ & $5.63 \pm 0.1^{\mathrm{b}, \mathrm{c}}$ & $5.32 \pm 0.2^{\mathrm{e}}$ & $4.90 \pm 0.3^{\mathrm{b}, \mathrm{c}}$ & $4.60 \pm 0.23^{c}$ & $3.02 \pm 0.7^{\mathrm{d}}$ & $2.92 \pm 0.10^{c}$ \\
\hline $6 \mathrm{Mm} \mathrm{ZnO}$ & $6.40 \pm 0.6^{\mathrm{a}}$ & $5.56 \pm 0.09^{c}$ & $5.43 \pm 0.1^{\mathrm{c}}$ & $5.40 \pm 0.6^{\mathrm{b}}$ & $4.71 \pm 0.1^{\mathrm{b}}$ & $4.61 \pm 0.68^{b}$ & $4.30 \pm 0.19^{b}$ \\
\hline $6 \mathrm{mM} \mathrm{TiO} 2$ & $6.40 \pm 0.9^{\mathrm{a}}$ & $5.93 \pm 0.1^{b}$ & $5.51 \pm 0.1^{\mathrm{b}}$ & $5.14 \pm 0.5^{b}$ & $4.94 \pm 0.3^{b}$ & $4.85 \pm 0.73^{b}$ & $4.27 \pm 0.24^{b}$ \\
\hline
\end{tabular}

The values are expressed as Mean \pm standard error of three experiments. Means within a column and rows followed by different letters are significantly different $(\mathrm{p} \leq 0.05)$.

\section{Sensory evaluation}

The chemical stability of meat during storage affects the sensory parameters. In general, sensory parameters are considered the most important factors in using any antibacterial nanoparticles. The effect of nanoparticles on overall acceptability (odor, color, and texture) of minced meat during refrigerated storage at $4{ }^{\circ} \mathrm{C}$ is presented in table 3 . Sensory properties were satisfactory for all the samples on the initial day of the storage $\left(1^{\text {st }}\right.$ day), however, they decreased during the storage period $(\mathrm{p} \leq 0.05)$. The results showed that all sensory attributes of control samples were acceptable by the $3^{\text {rd }}$ day of the storage period and spoiled at $6^{\text {th }}$ day; while treated samples were acceptable by the $15^{\text {th }}$ day of storage for texture, color, and overall acceptability attributes, by the $12^{\text {th }}$ day of storage for odor attribute. There was a significant difference $(\mathrm{p} \leq 0.05)$ for overall acceptability attribute between the treated and control samples on the days $3^{\text {rd }}, 6^{\text {th }}, 9^{\text {th }}$, $12^{\text {th }}, 15^{\text {th, }}$ and $17^{\text {th }}$ of the storage time. The concentrations of $12 \mathrm{mM} \mathrm{ZnO}, 12 \mathrm{mM} \mathrm{TiO} 2$, and the mixture of $\mathrm{ZnO}+\mathrm{TiO} 2$ $(6 \mathrm{~mm})$ enhanced shelf lifetime of minced meat and delayed its spoilage until $17^{\text {th }}$ day, while minced meat treated with concentrations of $6 \mathrm{mM} \mathrm{ZnO}$ and $6 \mathrm{mM} \mathrm{TiO} 2$ spoiled on $15^{\text {th }}$ day. Similarly, it is reported that the use of $\mathrm{TiO} 2$ delay spoilage of meat to 15 days (Alizadeh-Sani et al., 2020). Sensory evaluation of meat products allows researchers to evaluate how consumers perceive associated palatability. The reactions during lipid oxidation can lead to the formation of off-odors and off-flavors, texture, and color changes due to the myoglobin oxidation cause discoloration, which influences consumer's choice and acceptance. Aldehydes are important toxic compounds resulted during lipid oxidation cause organoleptic changes (Banerjee et al., 2017).

Table 3. Effects of different concentrations of $\mathrm{ZnO}$ and $\mathrm{TiO} 2$ nanoparticles on overall acceptability of minced meat during storage at $4{ }^{\circ} \mathrm{C}$ for 17 days.

\begin{tabular}{|c|c|c|c|c|c|c|c|}
\hline Groups & 1st day & 3rd day & 6th day & 9th day & 12th day & 15th day & $17^{\text {th }}$ day \\
\hline Control group & $8.85 \pm 0.08^{a}$ & $5.66 \pm 0.33^{b}$ & $3.66 \pm 0.06^{b}$ & $3.10 \pm 0.09^{c}$ & $2.20 \pm 0.06^{\mathrm{e}}$ & $1.50 \pm 0.08^{\mathrm{e}}$ & $1.10 \pm 0.10^{\mathrm{e}}$ \\
\hline $12 \mathrm{mM} \mathrm{ZnO}$ & $8.95 \pm 0.03^{a}$ & $8.88 \pm 0.06^{\mathrm{a}}$ & $7.66 \pm 0.33^{a}$ & $7.16 \pm 0.16^{\mathrm{a}}$ & $6.50 \pm 0.29^{a}$ & $5.66 \pm 0.33^{a}$ & $3.11 \pm 0.06^{\mathrm{a}}$ \\
\hline $6 \mathrm{mM} \mathrm{ZnO}+6 \mathrm{mM} \mathrm{TiO} 2$ & $8.95 \pm 0.03^{\mathrm{a}}$ & $8.71 \pm 0.11^{\mathrm{a}}$ & $7.50 \pm 0.29^{\mathrm{a}}$ & $7.13 \pm 0.13^{\mathrm{a}}$ & $6.16 \pm 0.16^{\mathrm{a}}$ & $5.73 \pm 0.39^{a}$ & $2.50 \pm 0.06^{b}$ \\
\hline $12 \mathrm{mM}$ TiO2 & $8.95 \pm 0.03^{a}$ & $8.56 \pm 0.29^{a}$ & $7.27 \pm 0.30^{a}$ & $7.13 \pm 0.09^{b}$ & $6.20 \pm 0.15^{b}$ & $5.46 \pm 0.26^{\mathrm{a}, \mathrm{b}}$ & $2.10 \pm 0.06^{d}$ \\
\hline $6 \mathrm{Mm} \mathrm{ZnO}$ & $9.25 \pm 0.28^{a}$ & $8.61 \pm 0.06^{\mathrm{a}}$ & $7.10 \pm 0.16^{\mathrm{a}}$ & $6.00 \pm 0.48^{b}$ & $5.26 \pm 0.12^{c}$ & $3.00 \pm 0.06^{b}$ & $2.00 \pm 0.12^{\mathrm{c}}$ \\
\hline $\mathrm{mM}$ TiO2 & $8.95 \pm 0.03^{a}$ & $8.62 \pm 0.12^{a}$ & $7.10 \pm 0.13^{a}$ & $6.10 \pm 0.06^{b}$ & $5.23 \pm 0.14^{\mathrm{c}}$ & $2.50 \pm 0.06^{b}$ & $2.00 \pm 0.14^{\mathrm{c}}$ \\
\hline
\end{tabular}

The values are expressed as Mean \pm standard error of three experiments. Means within a column and rows followed by different letters are significantly different $(\mathrm{p} \leq 0.05)$. 


\section{CONCLUSION}

It is concluded that nanoparticles have an antimicrobial effect against $E$. coli and their effect is concentration-dependent. It is demonstrated that $12 \mathrm{mM} \mathrm{ZnO}$ nanoparticles had a greater antimicrobial effect against E. coli than the mixture of $\mathrm{ZnO}+\mathrm{TiO} 2(6 \mathrm{mM})$, followed by $12 \mathrm{mM} \mathrm{TiO} 2$. It is found that these nanoparticles can prevent bacterial growth and enhance the shelf life of minced meat.

\section{DECLARATIONS}

\section{Acknowledgments}

The authors express their sincere gratitude to Animal Health Research Institute, Egypt for all the support provided, Cairo University Research Park (CURP), Egypt for using TEM and Spectroscopy Department, Physics Division, National Research Centre, Egypt for providing the nanoparticles.

\section{Authors' contributions}

Hemmat M. Ibrahim and Rasha Elsabagh designed the plan of study, revised the research article. Mohebat A. Abd El- Aziz, Rasha Elsabagh and Nahla Abo EL-Roos analyzed the data, performed laboratory experiments, and drafted the manuscript. Nahla Abo EL-Roos provided the experimental tools, revised the research article, Badawi Anis helped in the synthesis of nanoparticles and helped in the analysis of TEM pictures.

\section{Competing interests}

The authors declare no conflicts of interest.

\section{REFERENCES}

Ahmed AM and Ismail TH (2010). Improvement of the quality and shelf-life of minced beef mixed with soyprotein by Sage (Saliva Officinalis). African Journal of Food Science, 4(6): 330-334. Available at: http://www.academicjournals.org/ajfs/

Ali SS, Sonbol FI, Sun J, Hussein MA, Hafez AE, Abdelkrim EA, Kornaros M, Ali A and Azab M (2020). Molecular characterization of virulence and drug resistance genes-producing Escherichia coli isolated from chicken meat: Metal oxide nanoparticles as novel antibacterial agents. Microbial Pathogenesis, 19: 104-164. DOI: https://doi.org/10.1016/j.micpath. 2020. 104164

Alizadeh-Sani M, Mohammadian E and McClements DJ (2020). Eco-friendly active packaging consisting of nanostructured biopolymer matrix reinforced with $\mathrm{TiO} 2$ and essential oil: Application for preservation of refrigerated meat. Food Chemistry, 9:126782. DOI: https://doi.org/10.1016/j.foodchem.2020.126782

Ashe B (2011). A Detail investigation to observe the effect of zinc oxide and Silver nanoparticles in biological system. (Doctoral dissertation).

Avella M, De Vlieger JJ, Errico ME, Fischer S, Vacca P, and Volpe MG (2005). Biodegradable starch/clay nanocomposite films for food packaging applications. Food Chemistry, 93(3): 467-474. DOI: https://doi.org/10.1016/j.foodchem.2004.10.024

Baltić MŽ, Bošković M, Ivanović J, Dokmanović M, Janjić J, Lončina J and Baltić T (2013). Nanotechnology and its potential applications in meat industry. Tehnologija Mesa, 54(2): 168-175. DOI: http://doi.org/ 10.5937/tehmesa1302168B

Banerjee R, Verma AK and Siddiqui MW (2017). Control of lipid oxidation in muscle food by active packaging technology. In Natural Antioxidants, Apple Academic Press. pp. 363-402.

Baranowska-Wójcik E, Szwajgier D, Oleszczuk P and Anna WM (2020). Effects of Titanium Dioxide Nanoparticles Exposure on Human Health-a Review. Biological Trace Element Research, 193: 118-129. DOI: https://doi.org/10.1007/s12011-019-01706-6

Bauer AW, Kirby WMM, Sherris JC and Turck M (1966). Antibiotic susceptibility testing by a standardized single disk method, American Journal of Clinical Pathology, 45 (4): 493-496.

Butler DG, Cullis BR, Gilmour AR and Gogel BJ (2009). ASReml-R reference manual(release 3 edition). Queensland Department of Primary Industries and Fisheries: Brisbane.

Coles D and Frewer LJ (2013). Nanotechnology applied to European food production-A review of ethical and regulatory issues. Trends in Food Science and Technology, 34(1): 32-43. DOI: https://doi.org/10.1016/j.tifs.2013.08.006

Cullere M, Dalle Zotte A, Tasoniero G, Giaccone V, Szendrő Z, Szín M, Odermatt M, Gerencsér Z, Dal Bosco A and Matics Z (2018). Effect of diet and packaging system on the microbial status, $\mathrm{pH}$, color and sensory traits of rabbit meat evaluated during chilled storage. Meat Science, 141: $36-$ 43. DOI: https://doi.org/10.1016/j.meatsci.2018.03.014

Directive HAT (1994). European Parliament and Council Directive 94/36/EC of 30 June 1994 on colours for use in foodstuffs. Official Journal L, 237(10/09): 13-29.

Domínguez R, Barba FJ, Gómez B, Putnik P, Kovačević DB, Pateiro M, Santos EM and Lorenzo JM (2018). Active packaging films with natural antioxidants to be used in meat industry: A review. Food Research International, 113: 93-101. DOI: https://doi.org/10.1016/j.foodres.2018.06.073

Duncan DB (1955). Multiple range and multiple F tests. Biometrics, 11: 1-42. DOI: https://doi.org/10.2307/300147

Duncan TV (2011). Applications of nanotechnology in food packaging and food safety: barrier materials, antimicrobials and sensors. Journal of Colloid and Interface Science, 363(1): 1-24. DOI: https://doi.org/10.1016/j.jcis.2011.07.017

(EFSA) European food safety authority (2008). $21^{\text {st }}$ list of substances for food contact materials-Scientific Opinion of the Panel on food contact materials, enzymes, flavourings and processing aids (CEF). EFSA Journal, 6(12): 888.

Emami-Karvani Z and Chehrazi P (2011). Antibacterial activity of ZnO nanoparticle on gram-positive and gram-negative bacteria. African Journal of Microbiology Research, 5(12): 1368-1373. DOI: https:// doi.org/10.5897/AJMR10.159

Espitia PJP, Soares NFF, Coimbra JSR (2012).Zinc Oxide Nanoparticles: Synthesis, Antimicrobial Activity and Food Packaging Applications. Food Bioprocess Technology, 5:1447-1464. DOI: https://doi.org/10.1007/s11947-012-0797-6 
(FDA) Food and drug administration (2001). Bacteriological analytical manual online. Available at: http://www.fda. gov/Food/FoodScienceResearch/LaboratoryMethods/ucm2006949. htm>. Acessed: fev, 2, 2015.

(FDA) Food and drug administration (2015). http://www.fda.gov/forindustry/color-additives/coloradditiveinventories/ ucm115641.htm.

(ISO) International organization for standardization (2003). Sensory analysis - Methodology - General guidance for establishing a sensory profile( 13299). Available at: https://www.iso.org/standard/37227.html

(ISO) International organization for standardization (2012). Sensory analysis-general guidelines for the selection, training and monitoring of selected assessors and expert sensory assessors, ISO 8586. Available at: https://www.iso.org/standard/45352.html

Liu W, Zhao H, Qiu Z, Jin M, Yang D, Xu Q, Feng H, Li J and Shen Z (2019). Identifying geographic origins of the Escherichia coli isolates from food by a method based on single-nucleotide polymorphisms. Journal of Microbiological Methods, 105807. DOI: https://doi.org/10.1016/j.mimet.2019.105807

Liu Y, He L, Mustapha A, Li H, Hu Z and Lin M (2009). Antibacterial activities of zinc oxide nanoparticles against Escherichia coli O157: H7. Journal of Applied Microbiology, 107(4): 1193-1201. DOI: https://doi.org/10.1111/j.1365-2672.2009.04303.x

Marcous A, Rasouli S and Ardestani F (2017). Low-density polyethylene films loaded by titanium dioxide and zinc oxide nanoparticles as a new active packaging system against Escherichia coli O157: H7 in fresh calf minced meat. Packaging Technology and Science, 30(11): 693-701. DOI: https://doi.org/10.1002/pts.2312

Mihaly- Cozmuta A, Peter A, Mihaly- Cozmuta L, Nicula C, Crisan L, Baia L and Turila A (2015). Active packaging system based on Ag/TiO2 nanocomposite used for extending the shelf life of bread. Chemical and microbiological investigations. Packaging Technology and Science, 28(4): 271-284. DOI: https://doi.org/10.1002/pts.2103

Morsy MK, Elsabagh R and Trinetta V (2018). Evaluation of novel synergistic antimicrobial activity of nisin, lysozyme, EDTA nanoparticles, and/or $\mathrm{ZnO}$ nanoparticles to control foodborne pathogens on minced beef. Food Control, 92: 249-254. https://doi.org/10.1016/j.foodcont.2018.04.061

Othman SH, Salam A, Raudhah N, Zainal N, Kadir-Basha R and Talib RA (2014). Antimicrobial activity of TiO2 nanoparticle-coated film for potential food packaging applications. International Journal of Photoenergy, 2014. 6 pages. DOI: https://doi.org/10.1155/2014/945930

Sirelkhatim A, Mahmud S, Seeni A, Kaus NHM, Ann LC, Bakhori SKM, Hasan H and Mohamad D (2015). Review on zinc oxide nanoparticles: antibacterial activity and toxicity mechanism. Nano-Micro Letters, 7(3): 219-242. DOI: https://doi.org/10.1007/s40820-015-0040-x

Sofos JN and Geornaras I (2010). Overview of current meat hygiene and safety risks and summary of recent studies on biofilms, and control of Escherichia coli O157: $\mathrm{H} 7$ in nonintact, and Listeria monocytogenes in ready-to-eat, meat products. Meat Science, 86(1): 2-14. DOI: https://doi.org/10.1016/j.meatsci.2010.04.015

Toker R, Kayaman-Apohan N and Kahraman M (2013). UV-curable nano-silver containing polyurethane based organic-inorganic hybrid coatings. Progress in Organic Coatings, 76(9): 1243-1250. DOI: https://doi.org/10.1016/j.porgcoat.2013.03.023

Wang H, Xie C, Zhang W, Cai S, Yang Z and Gui Y (2007). Comparison of dye degradation efficiency using ZnO powders with various size scales. Journal of Hazardous Materials, 141(3): 645-652. DOI: https://doi.org/10.1016/j.jhazmat.2006.07.021

Xie Y, He Y, Irwin P L, Jin T and Shi X (2011). Antibacterial activity and mechanism of action of zinc oxide nanoparticles against Campylobacter jejuni. Applied and Environmental Microbiology, 77(7): 2325-2331. DOI: https://doi.org/10.1128/AEM.02149-10

Yashroy R (1990). Lamellar dispersion and phase separation of chloroplast membrane lipids by negative staining electron microscopy. Journal of Biosciences, 15(2): 93-98. DOI: https://doi.org/10.1007/BF02703373

Yin H, Wada Y, Kitamura T, Kambe S, Murasawa S, Mori H, Sakata T and Yanagida S (2001). Hydrothermal synthesis of nanosized anatase and rutile TiO2 using amorphous phase TiO2. Journal of Materials Chemistry, 11(6): 1694-1703. DOI: https://doi.org/10.1039/B008974P 